\title{
Use of a Thrombin Fibrin Sealant in Reducing Blood Loss in Revision Hip Arthroplasty
}

\author{
Ali Ghoz ${ }^{1}$, Hesham Al-Khateeb ${ }^{*}, 2$, Shanmugasundaram Rajkumar ${ }^{2}$, Shawn Tavares $^{3}$ and \\ Antonio Andrade ${ }^{3}$ \\ ${ }^{1}$ Hinchingbrooke Hospital, Hinchingbrooke Park, Hinchingbrooke, Huntingdon, Cambridgeshire PE29 6NT, UK \\ ${ }^{2}$ Department of Trauma and Orthopaedics, King Hamad University Hospital, Bahrain \\ ${ }^{3}$ Royal Berkshire Hospital, Craven Rd, Reading RG1 5AN, UK
}

\begin{abstract}
We present a retrospective evaluation assessing the use of a novel fibrin sealant, Quixil ${ }^{\circledR}$ (OMRIX Biopharmaceuticals S.A.) in reducing blood transfusions following revision total hip replacement surgery. Forty four patients underwent revision total hip replacement surgery using Quixil ${ }^{\mathbb{B}}$, while 45 patients underwent revision total hip replacement surgery without the use of Quixil ${ }^{\circledR}$. The duration of surgery and patient demographics were similar in both groups. Average blood loss was $1,010 \mathrm{ml}$ in the Quixil ${ }^{\mathbb{R}}$ group versus $1,021 \mathrm{ml}$ in the non-Quixil group. The use of cell saver and intra-operative blood transfusion were similar in both groups. The mean pre-operative Haemoglobin was 13.0 $\mathrm{g} / \mathrm{dl}$ in the Quixil ${ }^{\circledR}$ group versus $12.4 \mathrm{~g} / \mathrm{dl}$ in the non-Quixil group. The mean post-operative haemoglobin was $10.2 \mathrm{~g} / \mathrm{dl}$ and $9.1 \mathrm{~g} / \mathrm{dl}$ in the Quixil ${ }^{\circledR}$ and non-Quixil groups respectively. There was no difference in the blood transfused postoperatively between the two groups. Total units of blood transfused in Quixil ${ }^{\circledR}$ versus non-Quixil group were 60 verus 86. Total units of intra-operative blood transfused in Quixil ${ }^{\circledR}$ versus non-Quixil group were 16 versus 23 . The use of fibrin tissue adhesive in revision total hip arthroplasty seems to be an effective and reliable means to reduce blood-transfusion requirements and prevent post-operative decreases in hemoglobin.
\end{abstract}

Keywords: Arthroplasty, blood loss, fibrin glue, revision hip replacement, thrombin fibrin sealant, Quixil ${ }^{\circledR}$.

\section{INTRODUCTION}

Joint replacement surgery is on the rise with a growing number being performed every year [1]. With the increase in primary joint replacement surgery, there is a growing trend towards revision surgery. Revision total hip replacements are associated with significant intra-operative and postoperative blood loss requiring blood transfusion. This places a strain on blood banks. There have been various methods to try and reduce the allogenic blood transfusion requirements with its associated risks [2]. Clinicians are now concentrating their efforts on minimizing intra-operative blood loss during revision hip surgery through blood conservation methods and on avoidance of blood transfusion. The most appropriate solution is to reduce the loss of blood during and after an operation.

Various methods for blood conservation are available: pre-donation of autologous blood, erythropoietin treatment, intra-operative normovolaemic haemodilution, controlled hypotension, fibrin tissue sealants, antifibrinolytic agents, intra-operative and post-operative autologous blood collection and transfusion, and cell salvage [3]. Recently interest has focused on antifibrinolytic agents and fibrin tissue sealants. They have been shown to reduce both peri-

*Address correspondence to this author at the Department of Trauma and Orthopaedics, King Hamad University Hospital, Bahrain;

Tel: +97333884866; Fax: +97333884867;

E-mail: drheshamalkhateeb@msn.com operative and postoperative blood loss $[4,5]$. Fibrin sealants are haemostatic agents which when topically applied reduce the time required to achieve haemostasis and therefore reduce the volume of blood loss. They may provideadditional benefits, such as improved wound healing and decreased rates of wound infections [5-9].

We present a retrospective audit assessing the effectiveness of fibrin thrombo-sealant Quixil ${ }^{\circledR}$ (OMRIX Biopharmaceuticals S.A.) in reducing the amount of blood transfusion requirements following revision Total Hip Replacements. Quixil ${ }^{\circledR}$ is a first generation fibrin sealant containing two components, human clottable protein and human thrombin. When combined they form fibrin which cross links directly with exposed tissue collagen, anchoring tissues and clots to wound surfaces.

\section{METHOD AND MATERIALS}

We designed a retrospective study evaluating the use of Quixil $^{\circledR}$ at our hospital. We evaluated the blood transfusion requirements one year before the introduction of thrombin fibrin sealant and compared it with requirements following its introduction over a similar period. The medical records of the patients who underwent revision total hip replacement surgery in our hospital were reviewed. The clinical audit department at our institution approved the study. Two senior surgeons were involved in this study. We included all revision total hip replacement surgery, cemented and uncemented revisions, as well as partial (femoral or 
acetabular) and total (both femoral and acetabular) revisions. Anaesthetic and operative techniques were similar in both groups.

After thawing, the two constituents of the fibrin tissue adhesive Quixil $^{\mathbb{R}}$ vial are combined together by simultaneous application with the applicator using compressed air. Quixil ${ }^{\circledR}$ was then sprayed on the internal aspects of the operative field during and before skin closure. Blood loss during the operation was noted. The policy at our hospital was measuring the volume in the suction apparatus and weighting the swabs at the end of each operation. No drains were used post-operatively as per the senior surgeons practice. All blood transfusions requirements were noted from the medical records. The transfusion threshold at our institution was $<8 \mathrm{~g} / \mathrm{dL}$.

The primary end point in our study was the efficacy of the fibrin tissue adhesive in reducing the need for blood transfusion. The secondary endpoint was the magnitude of reduction in the haemoglobin levels. The need for blood transfusion was based on our departmental guidelines for blood transfusion.

\section{RESULTS}

There were 44 patients in the Quixil ${ }^{\circledR}$ group and 45 patients in the non-Quixil group. The patient demographics were similar in both groups with the exception of slightly older age patients in the Quixil ${ }^{\circledR}$ group. The mean age in the Quixil $^{\mathbb{R}}$ (OMRIX Biopharmaceuticals S.A.) group was 75.3 years (range 63-88 years) as compared to the mean age of 71.3 years (range $47-85$ years) in the non-Quixil group. The male: female ratio was $18: 26$ in the Quixil ${ }^{\mathbb{R}}$ group as compared to 17:28 in the non-Quixil group. The American Society of Anesthesiologists (ASA) grading of the patients within the two groups were similar and is shown in Table $\mathbf{1 .}$

Table 1. ASA grading of patients.

\begin{tabular}{|c|c|c|}
\hline ASA Grading & Quixil Group & Non-Quixil Group \\
\hline \hline 1 & 4 & 3 \\
\hline 2 & 22 & 23 \\
\hline 3 & 16 & 18 \\
\hline 4 & 2 & 1 \\
\hline
\end{tabular}

The type of revision implants used was similar between the two groups as was the indications for the revision surgery. There was no significant difference in intraoperative blood loss between the two groups. Operative times between the two groups were similar with no significant difference. Total number of patients transfused in the Quixil ${ }^{\circledR}$ group was 21 patients compared to 29 patients in the non-Quixil group (47\% versus 64\%). Total allogenic

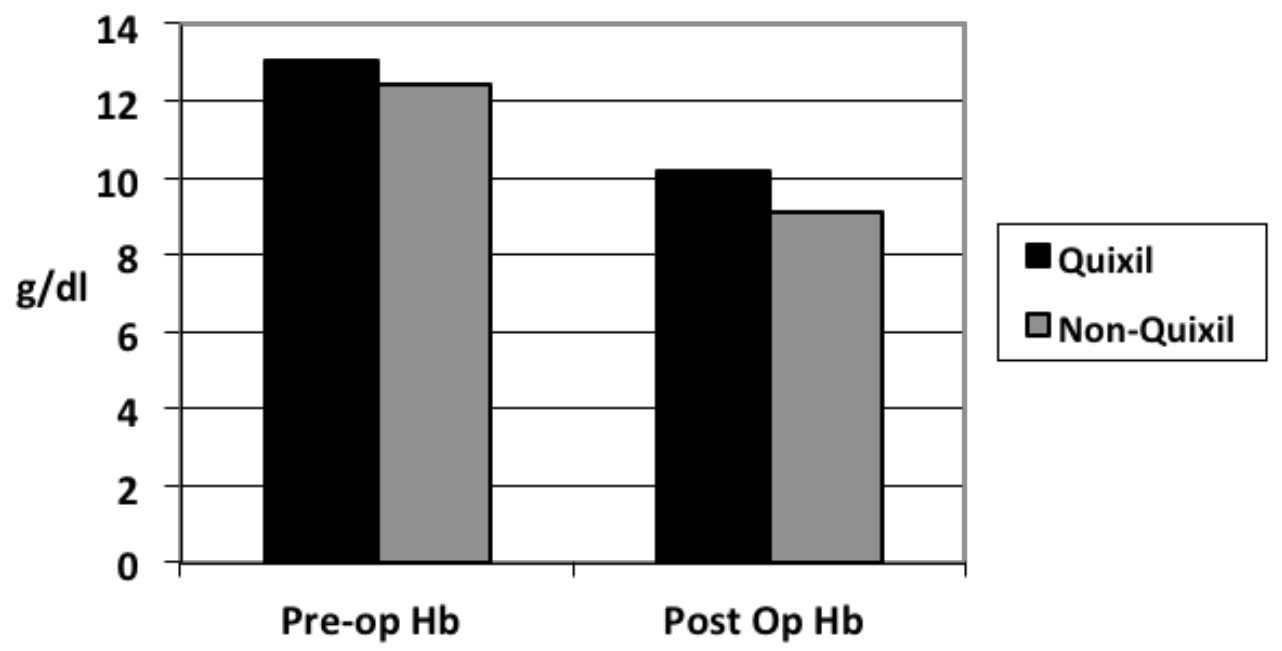

Fig. (1). Preoperative and postoperative Haemoglobin levels of Quixil ${ }^{\circledR}$ and non-Quixil groups.

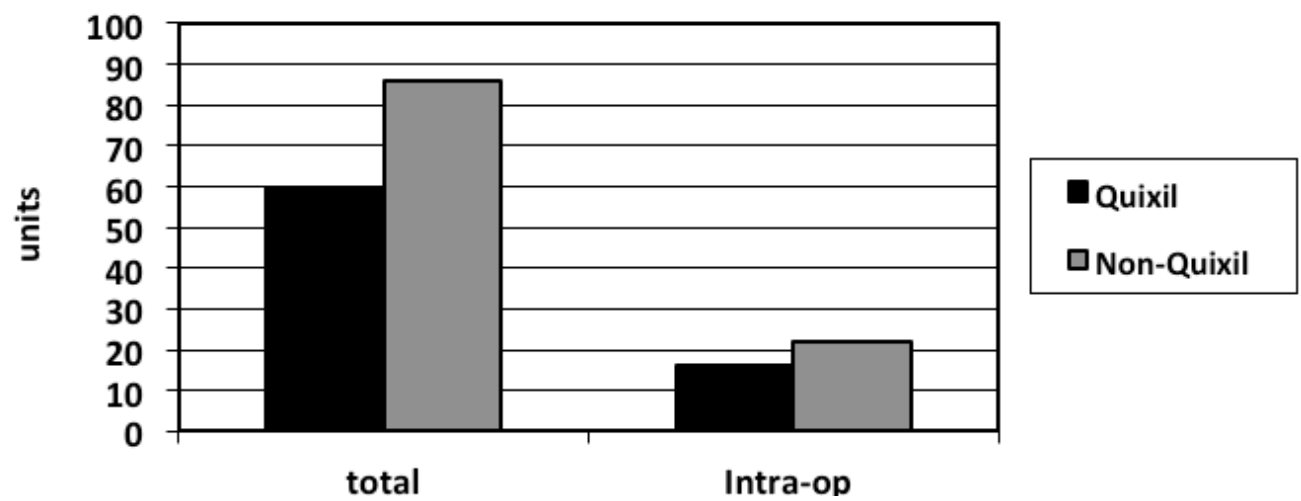

Fig. (2). Total units of blood transfused and number of units of blood transfused intraoperative in Quixil ${ }^{\circledR}$ and non-Quixil groups. 
blood units transfused in the Quixil ${ }^{\circledR}$ versus non-Quixil group was 60 versus $86(\mathrm{p}<0.05)$. Total allogenic blood units transfused intra-operatively in the Quixil ${ }^{\mathbb{B}}$ group was 16 patients compared to 23 patients in the non-Quixil group (Fig. 1). The mean pre-operative Haemoglobin of the Quixil $^{\circledR}$ group was $13.06 \mathrm{~g} / \mathrm{dl}$. The mean pre-operative Haemoglobin of the non-Quixil group was $12.4 \mathrm{~g} / \mathrm{dl}$. The mean post-operative Haemoglobin of the Quixil ${ }^{\circledR}$ group was $10.2 \mathrm{~g} / \mathrm{dl}$. The mean post-operative Haemoglobin of the nonQuixil group was $9.1 \mathrm{~g} / \mathrm{dl}$, a difference of $1.1 \mathrm{~g} / \mathrm{dl}$ (Fig. 2). These results are charted on Table 2.

Table 2. Comparison of quixil and non-quixil groups.

\begin{tabular}{|c|c|c|}
\hline & Quixil Group & Non-Quixil Group \\
\hline \hline Operating time & $2.4 \mathrm{hrs}(2-4 \mathrm{hrs})$ & $2.3 \mathrm{hrs}(2.1-3.9 \mathrm{hrs})$ \\
\hline Pre-op $\mathrm{Hb}$ & $13.06 \mathrm{~g} / \mathrm{dl}(9.7-16.2)$ & $12.4 \mathrm{~g} / \mathrm{dl}(8.8-16.2)$ \\
\hline Post-op Hb & $10.2 \mathrm{~g} / \mathrm{dl}(6.4-13.2)$ & $9.1 \mathrm{~g} / \mathrm{dl}(5.3-12.9)$ \\
\hline Cell saver & 6 patients & 6 patients \\
\hline Intra-op Blood loss & $\begin{array}{c}1010 \mathrm{mls} \\
(300-2200 \mathrm{mls})\end{array}$ & $\begin{array}{c}1021 \mathrm{mls} \\
(500-2000 \mathrm{mls})\end{array}$ \\
\hline
\end{tabular}

\section{DISCUSSION}

Various studies had looked at methods of reducing blood loss during liver and orthopaedic surgery. Schwartz et al. [10] in a prospective randomized multicentre trial of liver surgery showed reduction in intra-operative bleeding with the use of fibrin thrombo-sealants compared to standard topical agents with minimal complications.

The use of fibrin tissue adhesive in total knee arthroplasty as shown by Levy et al. [7] reduces the postoperative extravasation of blood into the tissues and subsequent formation of a hematoma. It was also found to significantly reduce the apparent blood loss, the decrease in the level of haemoglobin, the total calculated blood loss and the blood transfusion requirements $(\mathrm{p}<0.001$ for all). An analyses of 12 studies by Ho et al. [4] using transexamic acid, a constituent of Quixil ${ }^{\mathbb{R}}$, in both hip and knee replacements found that it reduces the proportion of patients requiring allogenic blood transfusion (OR $0.16,95 \%$ CI $0.09-0.26$ ), total amount of blood loss (mean $460 \mathrm{ml}, 95 \%$ CI $274-626 \mathrm{ml}$ ) and the total number of units of allogenic blood transfused. Wang et al. [11] concluded that the fibrin sealants reduce post-operative bleeding following total knee arthroplasty and minimize the drop in post-operative hemoglobin levels. They felt that the fibrin sealants may reduce the prevalence of post-operative deep vein thrombosis, pulmonary embolus, and death following knee arthroplasty. Clinical trials both in orthopaedic $[12,13]$ and liver surgeries [14] and have shown that fibrin thrombosealants can achieve rapid haemostasis even on large oozing and bleeding surfaces that cannot be controlled by conventional surgery alone. Reduced blood transfusion requirements have been demonstrated when fibrin thrombosealant was used in orthopaedic surgery [15-18]. A Cochrane review [17] of over 200 clinical trials found that antifibrinolytic drugs used at the time of major surgery reduced bleeding, the need for transfusions of red blood cells and the need for repeat surgery because of bleeding, without causing major adverse effects. The drugs reviewed were aprotinin, transexamic acid and epsilon aminocaproic acid. Carless et al. [18] in a systematic review of 12 trials utilizing fibrin sealants concluded that although the mean reduction in blood loss was an average of $150 \mathrm{ml}$, average transfusion requirements was reduced to 0.6 units $(60 \% \mathrm{RR}$ reduction).

Our observational study showed similar results to those mentioned above. The total number of patient who received blood transfusions was less in the group where the thrombin fibrin sealant was utilized. The number of intraoperative units and as well as the total number of units of blood transfused was less in this arm. Likewise the mean postoperative Haemoglobin was found to be higher $(10.2 \mathrm{~g} / \mathrm{dL})$ compared to the opposing group $(9.1 \mathrm{~g} / \mathrm{dL})$. Our results are in line with those of other Level 1 studies [15-18] and therefore it can be deemed that thrombin fibrin sealants are efficacious in reducing blood loss in revision total hip replacement surgery. Further randomized controlled trials involving revision total hip replacement surgery are needed to reaffirm this.

Quixil $^{\circledR}$ is biocompatible as well as biodegradable and therefore is not associated with inflammation, foreign body reactions, tissue necrosis, or extensive fibrosis. Fibrin sealants mimic the final phase of coagulation cascade through activation of fibrinogen by thrombin, which via a series of complex reactions leads to formation of clot and functions independently of the body's coagulation mechanism to work on patients with coagulopathies or on anticoagulation therapy. Once combined, fibrin clot is formed which cross links directly with exposed tissue collagen. Clot formation is by physiological coagulation cascade as well as fibrin tissue adhesive.

Quixil $^{\circledR}$ is a human surgical sealant composed of Biological Active Component (BAC) + Thrombin. The Biological Active Component consists of concentrate of human clottable proteins, $40-60 \mathrm{mg} / \mathrm{ml}$ tranexamic acid, arginine $\mathrm{HCl}$, glycine, sodium chloride, sodium citrate and calcium chloride. While the thrombin is constituted of 8000$1200 \mathrm{IU} / \mathrm{ml}$ human alpha thrombin, calcium chloride, human albumin, mannitol, and sodium citrate. BAC and Thrombin are manufactured from human plasma.

Each of the Quixil ${ }^{\circledR}$ components undergoes two separate and different virus inactivation and removal steps during manufacturing to reduce the risk of transmission of nonenveloped viruses and to add an additional margin of safety with respect to enveloped viruses. This also increases the probability of inactivating unidentified pathogens. The Biological Active Component is treated with solvent detergent followed by pasteurization. The Thrombin component undergoes solvent detergent treatment with subsequent nanofiltration. Quixil ${ }^{\circledR}$ is contraindicated in patients hypersensitive to human blood products or to one of the constituents of Quixil ${ }^{\mathbb{}}$.

Steuton et al. [19] conducted a cost model analysis and found that fibrin thrombo-sealants were cost effective in primary knee joint replacement surgery. Extrapolating to revision hip replacement surgery, we deduce fibrin thrombosealants to be cost effective as well. The cost of one unit of allogenic blood varies from $£ 125-200$ plus the hidden costs 
of increased hospital stay and treatment of complications ( $£ 300$ per day) adds up to $£ 425-500$ per day [20]. Moreover, one unit of blood transfused increases the hospital stay by one day on the average. Compared to this, the cost of fibrin thrombo-sealants Quixil $^{\circledR}$ is $£ 389$ per $5 \mathrm{ml}$ vial. To our knowledge, there have been no previous studies with use of fibrin thrombo-sealants in revision total hip replacement surgery. Furthermore, there are no studies looking at the efficacy of using fibrin thrombo-sealants in revision total hip replacement surgery.

The use of fibrin tissue adhesives in revision total hip replacement surgery seems to be a viable technique in reducing the blood loss, blood-transfusion requirements, as well as a decrease in the level of post-operative hemoglobin. It may also reduce the post-operative bleeding complications and the re-operation rates. Reducing allogenic blood transfusions minimizes the risk of transfusion reactions, virus transmissions, and time to recovery [21]. Allogenic blood transfusion itself may elevate the risk of serious infections and fluid overload through an immunomodulating effect [22].

We found our study to be limited by the following factors. It was conducted retrospectively and our patient pool was limited. We had no control over or assessment of patient factors such as comorbidities and current medications that may affect our outcome measures. Surgical factors such as approach used, type of implants removed/inserted, bone grafting, cementing, extended trochanteric osteotomy, a staged revision, infected revision could also have introduced bias to our study.

Though a trend of a reduction in blood transfusion requirements are demonstrated by our study, further high quality prospective controlled trials are needed to evaluate the efficacy and effectiveness of Quixil ${ }^{\mathbb{P}}$ in revision total hip replacement surgery with regards to length of stay, operative time, recovery and rehabilitation time.

\section{CONCLUSION}

The use of fibrin tissue adhesive in revision total hip arthroplasty seems to be an effective and reliable means to reduce blood loss, blood-transfusion requirements and a drop in post-operative haemoglobin. It appears to be cost effective alternative to prospective allogenic blood transfusions.

\section{CONFLICT OF INTEREST}

The authors confirm that this article content has no conflict of interest.

\section{ACKNOWLEDGEMENTS}

Declared none.

\section{REFERENCES}

[1] National Joint Registry of England and Wales. $6^{\text {th }}$ Annual Report 2009.

[2] Tenholder M. Cushner FD. Intraoperative Blood Management in Joint Replacement Surgery. Orthopedics 2004; 27(6 Suppl): s6638.

[3] Lemaire R. Strategies for blood management in orthopaedic and trauma surgery. J Bone Joint Surg Br 2008; 90(9): 1128-36.

[4] Ho KM, Ismail $\mathrm{H}$. Use of intravenous tranexamic acid to reduce allogenic blood transfusion in total hip and knee arthroplasty: a meta-analysis Anaesth Intensive Care 2003; 31(5): 529-37.

[5] Ido K, Neo M, Asada Y, et al. Reduction of blood loss using tranexamic acid in total knee and hip arthroplasties. Arch Orthop Trauma Surg 2000; 120(9): 518-20.

[6] Gill JB, Rosenstein A. The use of antifibrinolytic agents in total hip arthroplasty: a meta-analysis. J Arthroplasty 2006; 21(6): 869-73.

[7] Levy O, Martinowitz U, Oran A, Tauber C, Horoszowski H. The use of fibrin tissue adhesive to reduce blood loss and the need for blood transfusion after total knee arthroplasty. A prospective, randomized, multicenter study. J Bone Joint Surg Am 1999; 81(11): 1580-8.

[8] Thoms RJ, Marwin SE. The role of fibrin sealants in orthopaedic surgery. J Am Acad Orthop Surg 2009; 17(12): 727-36.

[9] Capdevila X, Calvet Y, Biboulet P, Biron C, Rubenovitch J, d'Athis F. Aprotinin decreases blood loss and homologous transfusions in patients undergoing major orthopedic surgery. Anesthesiology 1998; 88(1): 50-7

[10] Schwartz M, Madariaga J, Hirose R, et al. Comparison of a New Fibrin Sealant With Standard Topical Haemostatic Agents. Arch Surg 2004; 139(11): 1148-54.

[11] Wang GJ, Hungerford DS, Savory CG, et al. Use of fibrin sealant to reduce bloody drainage and hemoglobin loss after total knee arthroplasty. J Bone Joint Surg Am 2001; 83-A(10): 1503-5.

[12] Crawford RW, Giangrande P, Murray D. Fibrin sealant reduces blood loss in total hip arthroplasty. Hip Int 1999; 9: 127-32.

[13] Levy O, Martinowitz U, Oran A, Tauber C, Horoszowski H. The use of fibrin tissue adhesive to reduce blood loss and the need for blood transfusion after total knee arthroplasty. J Bone Joint Surg Am 1999; 81(11): 1580-8.

[14] Heaton N. Advances and methods in liver surgery: haemostasis. Eur J Gastroenterol Hepatol 2005; 17 Suppl 1: S3-12.

[15] Johansson T, Pettersson LG, Lisander B. Tranexamic acid in total hip arthroplasty saves blood and money: a randomized, doubleblind study in 100 patients. Acta Orthop 2005; 76(3): 314-9.

[16] Murkin JM, Shannon NA, Bourne RB, Rorabeck CH, Cruickshank M, Wyile G. Aprotinin decreases blood loss in patients undergoing revision or bilateral total hip arthroplasty. Anesth Analg 1995; 80(2): 343-8.

[17] Henry DA, Carless PA, Moxey AJ, et al. Anti-fibrinolytic use for minimising perioperative allogeneic blood transfusion. Cochrane Database Syst Rev 2011; 1: CD001886.

[18] Carless PA, Anthony DM, Henry DA. Systematic review of the use of fibrin sealant to minimize perioperative allogeneic blood transfusion. Br J Surg 2002; 89(6): 695-703.

[19] Steuten L, Vallejo-Torres L, Bastide P, Buxton M. Analysing uncertainty around costs of innovative medical technologies: the case of fibrin sealant (QUIXIL) for total knee replacement. Health Policy 2009; 89(1): 46-57.

[20] National Audit Office analysis of National Blood Service data. The National Blood Service. Available from: www.blooddonor.org.uk

[21] Madjdpour C, Spahn DR. Allogeneic red blood cell transfusions: efficacy, risks, alternatives \& indications. Br J Anaesth 2005; 95(1): 33-42

[22] Blajchman MA. Immunomodulation and blood transfusion. Am J Ther 2002; 9(5): 389-95. 